\title{
Biopolitics and legal issues of emergency situations in the context of coronavirus pandemic
}

\author{
Vladislav Denisenko ${ }^{1}$, and Elena Trikoz ${ }^{2,3, *}$ \\ ${ }^{1}$ Voronezh State University, Universitetskaya pl. 1, 394018, Voronezh, Russia \\ 2 Moscow State Institute of International Relations, prospect Vernadskogo 76, 119454, Moscow, \\ Russia \\ ${ }^{3}$ Peoples' Friendship University of Russia, Miklukho-Maklaya str. 6, 117198, Moscow, Russia
}

\begin{abstract}
It is difficult to overestimate the importance of biopolitical issues at the present time. The modern social state and the developing biolaw regulate a lot of private and public legal relations, especially the sensitive sphere of somatic and reproductive human rights, and the biological status of citizens. The most important aspect of national legal regulation, such as the ratio of law and morality, international biostandards, is being updated, and the status of bioethics and biolaw is being raised. The development of modern genetic engineering and biotechnologies raises the question of the legal boundaries of biopolitics. It has been found that national governments often expand biopolitical impact in situations of emergency and new biohazards, in particular, the COVID19 pandemic. The paper is prepared using doctrinal-legal and comparativesynchronous analysis of legal measures applied by different countries in the field of biopolitics. The research is based on extensive scientific and regulatory material. As a result, it was concluded that at the current stage of countering the pandemic, many countries restrict the biological rights of citizens and activate genetic technologies. The Russian and foreign experience of biopolitics in the state of emergency was studied.
\end{abstract}

\section{Introduction}

The future has already arrived in the context of a pandemic reality, when the state of national biosafety and global biopolitics for future generations seem obvious things. The social demand for an open and predictable state policy in relation to the human body, the protection of biological rights and freedoms, and the possible limits of the state's sovereignty over the somatic and reproductive human rights has grown stronger before our eyes.

The legal issue of self-isolation of citizens for the purpose of non-proliferation of the COVID-19 pandemic and legal regulation of biological rights in such emergency conditions has been put on the agenda. In 2020, many countries in Europe and America declared a state of emergency, which led to a number of legal bans and restrictions on personal status.

\footnotetext{
${ }^{*}$ Corresponding author: alena_trikoz@mail.ru
} 
The new reality began to be called a return to the concept of a walled city ("walled city" the term by Henry Kissinger), when human freedoms and biological rights are put in full dependence on the government.

Under these conditions, a new reading of the classical interpretation of Michel Foucault's biopolitics is developing [1], namely: it is directly associated with the development of biotechnologies and the emergence of "biocapital". The latter is understood not just as the process of using living organisms, but as "a special way of acquiring living nature (BIOS), literally-the capitalization of life" [2, p. 464]. Entire institutions and international organizations devote their activities to biopolitics (for example, the "Biopolitical International Organization", the International society for human ethology, the Committee on biological education, the Grooter Institute for law and behavioral research, and others were created not so long ago).

The object of a new type of biotechnology is the creation of values, profits and markets from biotic material and genetic information. To the old poles of biopolitics (individuals and communities) are added the cells, molecules, genes, neurotransmitters etc. A new way of influencing society is being developed through "influencing the human body nature with the help of a system of biomedical technologies" [3, p.40]. The rapid development of genetic engineering, biotechnologies and neuro and physiological research leads to the expanding control of the state over the citizen's body, genomic self-identity, and the privacy of biological information about a person and his family. Judicial practice is increasing in cases of cryo-preserved embryos obtained during in vitro fertilization, etc. The problem of Russian legislation on labeling of genetically engineered products, genetic diagnostics, and genetic certification of the population is becoming more acute. This is compounded by the narrowing of personal space in a digital millennium and biological privacy in a digital environment.

Right now, in the global fight against the COVID-19 pandemic, biopolitics is exerting powerful pressure on the protective barriers of human rights and freedoms. New points of intersection of bio - and geo-politics are emerging, national governments are reconsidering their attitude to natural ecosystems, and political systems are choosing a new strategy of behavior - biocentrism and biocracy.

The authors considered it important at the moment to show the legal basis for the control of the modern state over the body of its citizens, which seems to be the exception rather than the rule in conditions of clear threats to national security.

\section{Methodology}

The theoretical basis of the research consists of the works of domestic and foreign scientists devoted to the issues of biopolitics and bioethics, as well as problems of human rights protection. The phenomenon of biopolitics and its scientific and conceptual foundations have been studied in a number of general philosophical and humanistic works (Michel Foucault, Giorgio Agamben, T. Lemke, etc.) [4, p. 130-132]. According to M. Foucault, the modern state has always developed its disciplinary practices in all spheres of life of society, believing that the basic right of the sovereign is the right to the death or life of its nationals. If earlier the main authority of the sovereign power was based on the formula "to force one to die or allow one to live", then after the XIX century, according to Foucault, this sovereign right turns into its opposite: "to force one to live or allow one to die" [1, p.68].

The authors investigated various approaches to understanding the category "biopolitics". Of particular interest is the interpretation of biopolitics by representatives of the "American school" (P. Corning, R. Masters, A. Somit) and the interpretation of the Greek author A. Vlavianos-Arvanitis. The authors agree with the position of T. Lemke, who points to two semantic components of biopolitics. First, it is "life as the basis of 
politics", in which two ways of understanding life through biopolitology and state biology are distinguished. Secondly, it is "life as an object of policy", which also includes two areas-environmental and technocentric biopolitics. We have studied a number of studies on environmental biopolitics as a new policy course aimed "at preserving the natural human environment" [3, p. 23-24]. At the same time, "technocentric biopolitics", which is gaining momentum in state practice, focuses on problems related to the introduction of biotechnological innovations and issues of bioethical issues (DNA manipulation, prenatal diagnostics, etc.).

The authors used well-known methods of comprehensive assessment of legislation related to somatic and reproductive human rights. Provisions of international legal acts, Russian and foreign legislation, materials of judicial practice related to the concepts of biolaw and biosafety in a state of emergency were subjected to systematic interpretation.

\section{Results}

The reformatting of the modern state in the atmosphere of national security challenges such as bioterrorism and the COVID-19 pandemic is accompanied by an equally dangerous threat that a citizen may be deprived or restricted in their rights, including biological and environmental ones [5]. The specificity of the state of emergency declared in a number of States in the current period is expressed in the fact that it is presented "as a legal form of what can't have a legal form" [6]. After all, the state of emergency operates through exceptions, which applies both to the temporary abolition of formal (statutory) law, and to the spatial withdrawal of a certain territory of the state. Italian philosopher Giorgio Agamben calls this phenomenon of state control over the body "Homo sacer" [6].

A notorious example of this state of affairs, according to Agamben, is the historically established system of concentration camps that arose long before the Holocaust (for example, Indian camps in the United States in the 1830 s or British concentration camps during the Anglo-Boer war). Modern examples of this "exclusion space" are the Abu Ghraib and Guantanamo prisons, which ignore the rights of prisoners as citizens because they are not subject to either American criminal law or the 1949 Geneva Convention on the behavior of prisoners of war. This "exclusion space" is also possible in a situation of "extraordinary rendition" of a prisoner, when he is transferred to a place where the use of torture and other violations of human rights and freedoms are permissible. According to Agamben, the camp is the most obvious confirmation of the emptiness of "natural and universal" human rights, which are guaranteed only by international law, and not by the law and practice of specific States. Analyzing the concentration camps of the totalitarian regime, the German-American philosopher Hannah Arendt writes that "everything is possible" within such a regime, and international conventions could not help the Jews, who, like other "extra-state" and "denaturalized" minorities, were subjected to repression or simply destroyed.

As a result of comparing philosophical and humanistic positions on the phenomenon of biopolitics, we come to the conclusion that the state can fully regulate the life of citizens through legal procedures, legally control not only their social and political, but also their biological form of life. The counter-phenomenon of "society's legal system" develops, when during a century and a half of the development of the "social state" the subject of legal regulation is expanded and public law invades the most remote corners of the human self-identity as a biological species. Through the mechanism of exceptions in law, the actual elimination of the legal status of citizens occurs, the transition to a legal state of emergency, in which "exceptions without deadlines" become the norm [7].

New disciplinary techniques of power and procedures aimed at the individual human body are well known in M. Foucault's work "To supervise and to punish", where he lists 
new tools with which power does not suppress, but namely, produces individuals: the distribution of individual bodies in the space of places of "disciplinary monotony" (in barracks, colleges, factories, workhouses, prisons); training and drill, designed to simultaneously increase the economic utility of the body and its political "obedience", continuous observation (the principle of "panopticism"); an exam that allows classifying individuals and placing them on different hierarchical levels; and others [8].

All these individualizing disciplinary techniques and "anatomical politics" of the human body, known since the end of the XVIII - early XIX centuries, are supplemented by completely new technologies in the XX century. Today, "mass-identifying" biopolitics addresses the multiplicity of people and the human race, which constitute "a global mass affected by the general processes of life, such as birth, death, reproduction, disease, etc." [1]. A complex combination of disciplinary techniques and a new type of biopower (regulatory mechanism) becomes possible due to the fact that they are located at different levels: on the one hand, a row of "body - organism - discipline - institutions", and on the other, a row of "population - biological processes - regulatory mechanisms of the state" [1].

Revealing the history of the state of emergency in Western civilization, J. Agamben correctly explains that the absolute sovereign "hides" in the center of constitutional legality, and it controls the application or refusal to apply the rule of law, restricts the supremacy of law. The legal regime of the "state of emergency" was not just a mistake in the functioning of a democratic state in the twentieth century, but gradually turned from an exception to the rule, expanding the bases for the use of biohazards efforts.

At the beginning of the XXI century, the response of democratic States (primarily the United States, Great Britain, and Australia) to international terrorist attacks only confirms the concept of Agamben: the "state of emergency" was actually imposed, though implicitly. A number of national laws have restricted the rights and freedoms of citizens, increased surveillance of citizens and foreigners, and suspended legal procedures and international standards for interrogation, arrest and imprisonment. The state of emergency in the "war on terror" was declared for the entire period of the "war", and in fact, for an indefinite period.

The main feature of the state of emergency in the era of biopolitics is that "a simple return to normative law is impossible, since the law is produced by the "state of emergency" [6, p.12]. In a modern state with its rational law, a citizen can be completely deprived or significantly restricted in his legal status on legal basis (Table 1).

Table 1. Biopolitics in the context of coronavirus pandemic.

\begin{tabular}{|c|c|c|c|}
\hline Legal Regime & $\begin{array}{c}\text { Restriction of } \\
\text { Human Rights }\end{array}$ & \multicolumn{2}{|c|}{ Consequences } \\
\hline State of emergency & Parlament & \multicolumn{2}{|c|}{ Time restrictions } \\
\hline Hybrid regime & Regional authority & $\begin{array}{c}\text { Territorial } \\
\text { restrictions }\end{array}$ & $\begin{array}{c}\text { No common time } \\
\text { constraints }\end{array}$ \\
\hline
\end{tabular}

\section{Discussion}

As in most countries of the World, the Russian Federation introduced a number of human rights restrictions in the first half of 2020 in response to COVID-19. The Actually constitutional right of Russian citizens to freedom of movement, free acquisition of goods, works, services, as well as other economic and cultural rights and freedoms was restricted.

There are significant differences in the biopolitical strategy of Russia in the fight against COVID-19 compared to other countries, such as Italy, the Czech Republic, India, Iran, 
where a state of emergency was introduced, and in contrast, the opposite group of States whose governments refused to restrict civil rights and did not recognize the emergency of situation (Sweden, Belarus).

The specifics of the Russian legal regime for countering COVID-19 is its hybridity, that is, a mixture of new restrictions, bans and fines against the background of the refusal to introduce a state of emergency. As a result, there was legal uncertainty and vulnerability of the legal status of citizens in the Russian Federation. In the pandemic reality, citizens, individual entrepreneurs, and small and medium-sized businesses found themselves in an unprotected state, deprived of judicial protection mechanisms (in the context of the suspension of the work of Russian courts). Human rights were temporarily restricted, but the timing of the development and end of the pandemic is difficult to predict and the authorities have repeatedly extended the "regime of self-isolation" (or "the mode of increased readiness" - under Russian law).

But the problem of uncertainty and the duration of extreme restrictions on rights and freedoms in the context of a coronavirus pandemic is acute. The fact is that this infection is difficult to control due to the lack of obvious symptoms of the disease in many people. Thus, according to the Center for the study of infectious diseases at the University of Minnesota (USA), the COVID-19 pandemic may last for two years and will develop in waves until 2022 [9].

In the context of fighting against the COVID pandemic, the concept of a "walled city" is being revived, according to which the State has the right to refuse liberal human rights. According to Henry Kissinger, "the pandemic has prompted an anachronism, a revival of the walled city in an age when prosperity depends on global trade and movement of people. The world's democracies need to defend and sustain their Enlightenment values" [10]. In this situation, the global trend of deviation from the balance of power with legitimacy will continue. The transformation of States into "walled cities" in connection with the pandemic leads to the non-fulfillment of guarantees of individual rights under the pretext of temporary restrictions. This is likely to lead to the leveling of the concept of the social contract, both within States and in inter-state relations.

In Russia, in the context of unstable national security and new bio-threats, biopolitics is being legitimized. President Vladimir Putin issued a decree on March 1, 2019. "On the basis of the state policy of the Russian Federation in the field of security of chemical and biological safety". It is the first time that the introduction of genetic passports for Russians until 2025 is mentioned. The "Federal scientific and technical program for the development of genetic technologies for 2019-2027" set specific goals in this direction.

The COVID-19 pandemic, which broke out in early 2020, spurred the Russian government to engage in "accelerated development" of genetic technologies in order to become one of the world leaders in this field by 2027. Between the government and the company "Rosneft" signed an Agreement on cooperation, including with the aim of creating a Centre of comprehensive research in the field of genetic technology and genetic editing. Most likely, this Center will be engaged in the project "Genome of Russians", whose experts intend to focus on a complete genetic analysis of Russian residents and find out whether there are "genetic breakdowns" typical for the Russian ethnic group that can be installed and then edited.

Modern Russian legislation lags far behind in the development of biotechnologies, hindering the widespread introduction of genetic research into medical practice with its lack of development and prohibitions. In particular, the process of certification of equipment, software and reagents for genetic testing in clinics is highly regulated. "Extreme genetics" in Russia does not lend itself to legal description, although experts are already ready to offer their services to study the DNA of murderers and genes of other dangerous behavior, to predict behavior by genome. The problem of developing a "code of genomic research" 
that will take into account the legal and ethical aspects of DNA manipulation is being updated. In the Russian Federation, genetic modification of plants and animals is legally prohibited, which, according to scientists and bioexperts, hinders the industrial leap in the agricultural and food sectors.

National biopolitics should not override international standards in the field of biotechnologies and biomedical research. The problem is that most of these international norms are soft law, and only gradually a block of conventions is being formed (for example, the Council of Europe Convention on the protection of human rights and dignity in connection with the application of advances in biology and medicine in 1997). The specificity of the principles and rules of international bio-standards is that they were formed on the basis of medical deontology as an offshoot of the ethical principles and rules of interaction between a doctor and a patient [11]. In this context, the question arises of translating these ethical norms into national legislation. We will need legal experts who will be able to provide qualified legal interpretation and specification in court practice.

The key role of international and national organizations operating in a state of emergency for the common purpose of preserving and guaranteeing human rights should be recognized. We are talking about national committees on bioethics at UNESCO, as well as other organizations that are built on the idea of a communicative mind. In such decisionmaking, the practical wisdom of "people from the street" turns out to be equal to the accumulated knowledge of philosophers and scientists, and equally responsible for solving the problems of life and death that arise in the most acute bioethical situations [12, p.77]. The existence of such procedures allows preserving the guarantees of citizens' rights in the conditions of isolation of citizens and ensuring the legitimacy of the law.

\section{Conclusion}

Based on the conducted research, it can be concluded that today, the policy of many countries operates in a state of emergency, which leads to changes in legal regulation. A state of emergency allows exceptions to replace general rights for security reasons. Exceptions can be either spatial or temporary. They put whole groups of people in a state without legal protection. In the context of protection from COVID-19, national legislation should apply international bioethics law and deliberative procedures to ensure the legitimacy of the law. Modern biopolitical needs to be proactive in lawmaking.

Part of this research conducted by the co-author of the article is V.V. Denisenko, has been supported by RFBR (the project No. 18-011-001777).

\section{References}

1. M. Foucault, Science as Culture. 17 (4), 463-478 (2008)

2. Th. Lemke, Biopolitics. Advanced Introduction (New York, New York University Press, 2011)

3. I.I. Kobylin, Istok and Singularity: J. Agamben and M. Foucault on the birth of biopower, Philosophy and society, 3 (63), 130 (2011)

4. A. Malinovsky, D. Osina, E. Trikoz, Legal instruments for stimulating environmentally friendly behavior: successful practices in Russia and abroad, E3S Web of Conferences, 164, 1-11 (2020)

5. G. Agamben, Homo sacer. State of emergency (EUROPE, Moscow, 2011) 
6. M. Antonov, V. Denisenko, Thinking law as communication, Review of Central and East European Law, 40(2), 189-201 (2015)

7. M. Foucault, To supervise and to punish. The birth of a prison (Ad Marginem, Moscow, 1999)

8. J. Lauerman, Coronavirus Pandemic Likely to Last Two Years, Report Says (1 May, Bloomberg, 2002)

9. H. Kissinger, The Coronavirus Pandemic Will Forever Alter the World Order, https://www.henryakissinger.com/articles/the-coronavirus-pandemic-will-forever-alterthe-world-order/ (date of issue: 30.04.2020)

10. V.V. Lapaeva, International regulation of relations in the field of biomedicine: interaction of law and morality, Pravo. Journal of the Higher school of Economics, 2, 22-44 (2019)

11. P.D. Tishchenko, Bio-power in the era of biotechnologies (IFRAS, Moscow, 2001) 